\title{
ETHICAL DEVELOPMENT AND THE GROWTH OF PUBLIC SECTOR IN NIGERIA
}

\author{
Onwuama, Emeka Michael, Ph.D \\ Humanities Unit, School of General Studies \\ University of Nigeria, Enugu Campus \\ Email: emeka.onwuama@unn.edu.ng \\ Obiora, Anichebe, Ph.D. \\ Department of Philosophy, University of Nigeria
}

\section{The study was to evaluate the ethical development and the growth of public sector in Nigeria.} The specific objectives were to: determine the relationship between equality and employment opportunities in the public sector in Nigeria, examine the relationship between technoethics and creation of infrastructure in Nigeria and evaluate the relationship between diversity and generation of financial resources in public sectors in Nigeria. The area of study focused on 25 ministries of the public sector from South East, Nigeria. They study covered period of (20102020). The study used the survey approach. The primary sources were personal interview and the administration of questionnaire to the management and staff of the manufacturing firms. The population for the study was Six thousand, seven hundred and thirteen staff $(6,713)$ of the ministries. The study sample size, Nine hundred and seventeen (363) respondents was chosen after applying the Freund and William's formula for the determination of adequate sample size. A total of three hundred and sixty three (363) copies of the questionnaire were distributed to the respondents from which three hundred and forty three (343) copies were returned while twenty copies (20) were not returned. That gave 95 percent response rate. The validity of the instrument was tested using content analysis and the result was good. The reliability was tested using the Pearson correlation coefficient (r). It gave a reliability coefficient of 0.84 which was also good. The findings indicated that there is a significant relationship between equality and employment opportunities in public sector in Nigeria with two-tailed test $\mathrm{r}(95, \mathrm{n}=343)=.878, \mathrm{p}<.05)$, Technoethics and creation of infrastructure are significantly related with two-tailed test $\mathrm{r}(95, \mathrm{n}=343)=.735, \mathrm{p}<.05)$ and Diversity and generation of financial resources in public sectors in Nigeria are significantly related with two-tailed test $r(95, \mathrm{n}=343)=.679, \mathrm{p}<.05)$. The study concluded that there is a relationship between equality, technoethics, diversity and employment opportunities, creation of infrastructure, and generation of financial resources in the public sector in Nigeria. The study recommended that ethical use of technology should be encouraged by devising thoughtful principles that could help to guide new technological advances in public sector in Nigeria.

Keywords: Ethical development, Technoethics, Diversity, Equality, Employment opportunities, Creation of Infrastructure, Generation of financial resource.

\subsection{Introduction}

There is always a need for appropriate ethical conduct in any organization to ensure a smooth flow of activities. Rich (2013) in defining ethics as a philosophical discipline of study, sees it as a systematic approach to understanding, analyzing, and distinguishing matters of right and 
wrong, good and bad, and admirable and deplorable as they relate to the well-being of and the relationship among sentient beings. Also, ethical determinations are applied through the use of formal theories, approaches and codes of conduct, such as codes that are developed for professions and religions. Steinberg (2012) sees ethical development as application of moral principles in a given situation. It means to behave according to the moral standards set by the society which we live in. It identified in both individual relationships and work relationships. Ethics in organizational performance has long been associated with management scholars and business leaders around the world. There is a broad agreement around the world that as a matter of corporate policy, every organization strives to be committed in a manner that is ethically transparent. The performance of an organization is sometimes based on the ethical work environment. Thus, strong ethical climate provides employees a foundation for thinking about moral issues (Kehinde, 2017). Although organization members may reason effectively about the right thing to do, translating reason into action depends on the moderating effect of two additional contextual factors; collective moral emotion (Ebitu and Beredugo, 2015).

Furthermore, public sector growth basically refers to the expansions in the size of the public sector. The public sector includes agencies of government with specific services to provide, and more generally, activities under the jurisdiction of the government. The growth of the public sector is somewhat affected by the behaviour and conduct of the various individuals that work within it. It is obvious that how these individuals working in the public sector act and portray themselves will affect the organization in varying levels. Proper conduct from workers in the public sector helps to ensure that the goals and objectives of the organization are met. This is to say that there is a positive relationship between ethical development and the growth of public sector in Nigeria. This means that when the ethical behaviour improves, the public sector will witness more growth. Also, when the levels of ethical conduct in an organization are low, the growth of such organizations will also be hampered.

\subsection{Statement of the Problem}

The nature of human beings to indulge in actions that most times borders on morality has largely increased the importance of ethical development in Nigerian public sector. The development of an ethical culture improves the performance of any organization. When there is a uniform effort made by the members of a public organization in adhering to the recognized norms in the society, the implication is that there will be progress. Ethical development helps to squash various forms of corruption and ethnocentricism in government organizations. This is because it will create a situation where each individual does what he is expected to do, without elements of unethical practices.

However, the existence of stipulated norms does not merely induce compliance with it. Often times, public officers engage in unethical behaviours in their workplaces, that hamper the growth of the organization. These unethical practices could come in the form of employment discriminations or favoritism. Others could also come in the form of bribery and corruption. These actions of public agents usually hinder the growth of the public sector in Nigeria. There is the issue of inequality in provision of employment opportunities, where a vested authority uses his position to offer certain individuals employment in the organization regardless of their qualifications. There is also the problem of infrastructural development and the inequality of its distribution. This is to say that technology often times have not been properly utilized in the areas necessary. Then there is the problem of lack of diversity resulting from poor ethical behaviour of public organizations in Nigeria.

Furthermore, the existence of these problems calls upon the decisive actions of the government in controlling and regulating such actions. Failure to do so may culminate in various consequences. One of such consequences is that the lack of equality in the public organization is going to hamper employment provided by the public sector. Also, without the 
application of ethical considerations in the creation of infrastructure in the public sector, there would be an uneven distribution of such infrastructure and the organization with the society at large being on the receiving end of the hazard associated with such infrastructure. There is also the problem of lack of diversity in terms of the human resources available in the public sector. Such problem could hamper the ability of the sector to generate financial resources. Therefore, in the light of all these problems and their associated consequences, this study seeks to examine ethical development and the growth of public sector in Nigeria.

\subsection{Objectives of the study}

The main objective of the study was to evaluate the ethical development and the growth of public sector in Nigeria. The specific objectives were to;

i. Determine the relationship between equality and employment opportunities in the public sector in Nigeria

ii. Examine the relationship between technoethics and creation of infrastructure in Nigeria

iii. Evaluate the relationship between diversity and generation of financial resources in public sectors in Nigeria.

\subsection{Research Questions}

The following research questions guided the study;

i. What is the relationship between equality and employment opportunities in Nigeria public sector

ii. What is the relationship between technoethics and creation of infrastructure in public sector in Nigeria

iii. What is the relationship between diversity and generation of financial resources in public sectors in Nigeria

\subsection{Statement of Hypotheses}

The following alternate hypotheses guided the study

i. There is a significant relationship between equality and employment opportunity in public sector in Nigeria

ii. Technoethics and creation of infrastructure are significantly related

iii. Diversity and generation of financial resources in public sectors in Nigeria are significantly related

\section{REVIEW OF RELATED LITERATURE}

\subsection{Conceptual Framework}

\subsubsection{Ethical Development}

This is the application of moral principles in a given situation. It means to behave according to the moral standards set by the society which we live in. It identified in both individual relationships and work relationships. The concept can also be applied to corporations as entities. It evaluates the moral implications of actions being taken on each of the previously mentioned contexts. An ethical development is essential for a society to function properly. Individuals that behave unethically will normally loss other people's confidence and their unethical behaviour should be also punished by the law. They include both laws and morals, which determine how an employee will act in the business world (Sternberg, 2012). The physical attributes, language skills, and reasoning capabilities develop as we get older. Ethical philosophers believe that we also "grow up" in our ethical development. Kohlberg believed that people develop from rudimentary understanding to a more advanced knowledge and practice of ethics (Crocker, 2013). He developed three levels of development: The first 
level represents an elementary understanding of ethical development that focuses on avoiding personal punishment and meeting personal needs. Kohlberg explains that a child will not avoid stealing because stealing is wrong, but will avoid stealing in order to avoid punishment. At level two, an individual might do what is right, but will do so in order to maximize personal gain.

Individuals begin to consider others in addition to themselves, but they often act ethically in order to appear as a good person or to fulfill professional obligations. For example, many professionals will act ethically because they have agreed to follow a professional code of conduct. Kohlberg believed that most adults reach this level and are heavily influenced by a desire to be perceived as a "good person." The final level is considered the highest level of ethical development, and according to Kohlberg, reached by few adults. At this level, professionals show a genuine interest in the welfare of others and have a deep sense of universal ethical principles that guide their behaviour. These stages of ethical development move professionals from a basic individual concern to a recognition of their behaviour on others. Bivins (2010) conceptualized this development as moral obligations, identifying five specific moral obligations for public relations practitioners: To themselves to preserve their own integrity, to clients to honor contracts, to use professional expertise in their behalf, to organizations/employers to adhere to organizational goals and policies, to the profession/colleagues to uphold the standards of the profession, to society to consider societal needs and claims. Like Kohlberg's levels, these obligations progress from an individual ethical orientation to an outward ethical orientation, such a progression is inherent in a deeper understanding of ethical public relations literacy. As professionals become more ethically literate, they have an increased understanding of the concentric influence of their ethical behaviour on others (Sternberg, 2012).

\subsubsection{Public Sector Growth}

In general terms, the public sector consists of governments and all publicly controlled or publicly funded agencies, enterprises, and other entities that deliver public programs, goods, or services. The concept of public sector is broader than simply that of core government and may overlap with the not-for-profit or private sectors. The public sector consists of an expanding ring of organizations, with core government at the center, followed by agencies and public enterprises. Around this ring is a gray zone consisting of publicly funded contractors and publicly owned businesses, which may be, but for the most part are not, part of the public sector. The public sector might provide services that non-payer cannot be excluded from (such as street lighting), services which benefit all of society rather than just the individual who uses the service (such as public education), and services that encourage equal opportunity (Dube and Danescu, 2011).

Furthermore, the Oxford Advanced Dictionary defines growth the act or process, or a manner of growing; development; gradual increase or the development from a simpler to a complex stage. Therefore, going by the definitions advanced above, and based on the context of this paper, it therefore shows that public sector growth refers to the gradual increase in the size and structure of the public sector.

\subsubsection{Equality}

Equality before law means that the law applies to all peoples without exceptions, therefore the law must be designed beforehand in a way that discrimination by the state become unthinkable. Fairness and justice concept should be followed and enforced by the state (William, 2011).

Equality is about ensuring that every individual has an equal opportunity to make the most of their lives and talent. It is also the belief that no one should have poorer life chances because 
of the way they were born, where they came from, what they believe in or whether they have a disability. Equality recognizes that historically certain groups of people with protected characteristics such as race, disability, sex and sexual orientation have experienced discrimination (EHRC, 2018)

\subsubsection{Employment Opportunities}

The Cambridge English Dictionary defines employment as the fact of someone being paid to work for a company or an organization. The first dimension of employment measurement relates to opportunities. This dimension refers to the quantity of jobs created by a youth employment intervention, with the primary indicator being the employment rate of project beneficiaries (ILO, 2018).

The International Labour Organization defines employment from a people-centric perspective (i.e. whether an individual is employed, underemployed or unemployed), rather than focusing on a job as the unit of analysis. The "employed" comprise all persons who worked for pay, profit or family gain for at least one hour in the reference week plus the number of persons who are temporarily absent from their jobs (ILO, 2013a.). This means that employment opportunities refer to the varying levels of access that an individual has to gain meaningful employment.

\subsubsection{Technoethics}

Technoethics views technology and ethics as socially embedded enterprises and focuses on discovering the ethical use of technology, protecting against the misuse of technology, and devising common principles to guide new advances in technological development and application to benefit society (Mike, 2017). Technoethics is an interdisciplinary research area that draws on theories and methods from multiple knowledge domains (such as communications, social sciences information studies, technology studies, applied ethics, and philosophy) to provide insights on ethical dimensions of technological systems and practices for advancing a technological society. Performing the role of technoethicists HR can at least make sure that the proper consideration is given to the people versus technology decisions that management teams will make (Mike, 2017).

Technoethic views technology and ethics as socially embedded enterprises and focuses on discovering the ethical use of technology, protecting against the misuse of technology, and devising common principles to guide new advances in technological development and application to benefit society (Luppicini, 2010). It is study of moral legal and social issues involving technology. Technoethics denotes a broad range of ethical issues revolving around technology from specific areas of focus affecting professionals working with technology to broader social, ethical, and legal issue concerning the role of technology in society and everyday life (Stephen, 2009). The ethical use of new technologies is important in society today, particularly in areas where technological advances have a transforming effect on society. Moor (2005) referred to this transforming effect of technology as a technological revolution, which he argued was connected to growing ethical problems.

Galvan (2001) defined technoethics as the sum total of ideas that bring into evidence a system of ethical reference that justifies that profound dimension of technology as a central element in the attainment of a 'final-ized' perfection of man. Bao and Xiang (2006) defined technoethics as the behavioural norm and ethical basis for the global community. It deals with human processes and practices connected to technology which are embedded within social, political, and moral spheres of life. It also examines social policies and interventions occurring in response to issues generated by technology development and use. This includes critical debates on the responsible use of technology for advancing human interests in society. 
The growing field of technoethics is based on the premise that it's of vital importance to encourage dialogue aimed at determining the ethical use of technology, guarding against its misuse, and devising thoughtful principles that help to guide new technological advances for the benefit society in a variety of social contexts and ethical dimensions. Technoethics is not only an intellectually analytical process, it is also a cultural product with serious implications for understanding some of the "none-too-visible" dimensions of how policies and decisions about technology are made (Stephen, 2009).

\subsubsection{Infrastructure}

Infrastructure refers to the sum of material, institutional and personal facilities and data which are available to the economic agents and which contribute to realizing the equalization of the remuneration of comparable inputs in the case of a suitable allocation of resources, that is complete integration and maximum level of economic activities (Jochimsen, 1966, cited in Torrisi, 2009 p.7)

Infrastructure is the fundamental facilities and systems serving a country, city, or other area, including the services and facilities necessary for its economy to function (O'Sullivan \&Sheffrin, 2003). Infrastructure is composed of public and private physical improvements such as roads, railways, bridges, tunnels, water supply, sewers, electrical grids and telecommunications. In general, it has also been defined as the physical components of interrelated systems providing commodities and services essential to enable, sustain, or enhance societal living conditions.

There are two general types of ways to view infrastructure, hard or soft. Hard infrastructure refers to the physical networks necessary for the functioning of a modern industry. This includes roads, bridges, railways, etc. Soft infrastructure refers to all the institutions that maintain the economic, health, social, and cultural standards of a country. This includes educational programs, official statistics, parks and recreational facilities, law enforcement agencies and emergency services (Fulmer, 2009).

\subsubsection{Diversity}

Diversity encompasses acceptance and respect. It means understanding that each individual is unique, and recognizing our individual differences. These can be along the dimensions of race, ethnicity, gender, sexual orientation, socio-economic status, age, physical abilities, religious beliefs, political beliefs, or other ideologies. In an organizational context, diversity refers to equality of opportunity and employment without any bias because of these traits. Rather, there are many barriers to diversity even after strenuous efforts by activists and experts and these relate to societal mindsets and personal psychological discomfort with having people drawn from diverse backgrounds working alongside (Management Study Guide, 2015).

Workplace diversity is an issue that has increasingly become a talking point in many businesses particularly, in human resources departments. Although some managers may feel legally compelled to create a diverse workforce, others may see the strategic benefits of having a broad range of types of employees. The term diversity includes and understanding and acceptance of the fact that people have individual characteristics, which make them unique from each other, particularly when comparing individuals in a group. These characteristics may include race, ethnicity, gender, religion, political ideologies, sexual orientation, age, physical abilities or socio-economic status. These characteristics also may include life experiences and cognitive approaches toward problem solving (Natter, 2019).

A company that can successfully manage a diverse workplace has a solid advantage over companies that don't embrace diversity so readily. A diverse workplace may facilitate employment in far-flung parts of the world. The idea of a central office or single meeting 
space might vanish, replaced by virtual hubs that stay in contact via email and online communication. For example, a company that opens a new branch in India may need to stay in contact with the Indian employees, transforming a single office environment into an interconnected virtual office. With diversity comes new means of expression, as employees from different cultures and backgrounds communicate in slightly different ways. This can lead to confusion and frustration, as missed signals result in miscommunication, and thus lost productivity (Vaux and Michelle 2019).

\subsection{Theoretical Framework}

\subsubsection{Stakeholders Theory}

In 1984, R. Edward Freeman originally detailed the Stakeholder Theory of organizational management and business ethics that addresses morals and values in managing an organization. The stakeholder theory is a theory of organizational management and business ethics that accounts for multiple constituencies impacted by business entities like employees, suppliers, local communities, creditors, and others (Tom, 2018). It addresses morals and values in managing an organization, such as those related to corporate social responsibility, market economy, and social contract theory. The stakeholder view of strategy integrates both a resource-based view and a market-based view, and adds a socio-political level. One common version of stakeholder theory seeks to define the specific stakeholders of a company (the normative theory of stakeholder identification) and then examine the conditions under which managers treat these parties as stakeholders (the descriptive theory of stakeholder salience) (Roberts, 2003). In fields such as law, management, and human resources, stakeholder theory succeeded in challenging the usual analysis frameworks, by suggesting that stakeholders' needs should be put at the beginning of any action (Harrison and De Colle, 2010). Some authors, such as Geoffroy Murat, tried to apply stakeholder's theory to irregular warfare. Stakeholder theory succeeds in becoming famous not only in the business ethics fields. It is used as one of the frameworks in corporate social responsibility methods.

The general idea of the Stakeholder concept is a redefinition of the organization. In general the concept is about what the organization should be and how it should be conceptualized. Friedman (2006) states that the organization itself should be thought of as grouping of stakeholders and the purpose of the organization should be to manage their interests, needs and viewpoints. This stakeholder management is thought to be fulfilled by the managers of a firm. The managers should on the one hand manage the corporation for the benefit of its stakeholders in order to ensure their rights and the participation in decision making and on the other. This theory is concerned with how managers and stakeholders actually behave and how they view their actions and roles. The instrumental stakeholder theory deals with how managers should act if they want to flavor and work for their own interests. In some literature the own interest is conceived as the interests of the organization, which is usually to maximize profit or to maximize shareholder value. This means if managers treat stakeholders in line with the stakeholder concept the organization will be more successful in the long run.

\subsubsection{Expectancy Theory}

In 1964, Victor H. Vroom developed the expectancy theory through his study of the motivations behind decision making. This theory is relevant to the study of management. Expectancy theory is proposes that an individual will behave or act in a certain way because they are motivated to select a specific behaviour over others due to what they expect the result of that selected behaviour will be (Oliver, 1974). In essence, the motivation of the behaviour selection is determined by the desirability of the outcome. However, at the core of the theory is the cognitive process of how an individual processes the different motivational elements. This is done before making the ultimate choice. The outcome is not the sole 
determining factor in making the decision of how to behave (Oliver, 1974). Expectancy theory is about the mental processes regarding choice, or choosing. It explains the processes that an individual undergoes to make choices. In the study of organizational behaviour, expectancy theory is a motivation theory first proposed by Victor Vroom of the Yale School of Management. This theory emphasizes the needs for organizations to relate rewards directly to performance and to ensure that the rewards provided are those rewards deserved and wanted by the recipients (Montana and Charnov, 2008).

Employees face an array of moral issues in their everyday decision making. Environmental concerns, employee and community welfare, and the interests of other companies (competitors, customers, and suppliers) are only a few examples. Yet, industries do not always address the issue of how employees should assess the moral import of their actions and incorporate these considerations into their decisions. As a result, moral considerations are often ignored, leading to unethical practices which may hurt the long-term interests of the company. In this paper, we present a model to help eliminate this problem. Organizations model uses expectancy theory as process theory of motivation to show that teaching employees to engage in moral reasoning, and creating a corporate culture in which ethical behaviour is both encouraged and rewarded, can increase the likelihood that a company's employees will act ethically (Robert and Schlacter, 1999).

\subsection{Empirical Review}

Mahjob (2018) conducted a study on the role of business ethics in improving the quality of job performance. The primary objective of the current study was to assess the validity of a new questionnaire for measuring ethical leadership. The study made use of descriptive and analytical research design for attaining outcomes. The study showed that business professionals are well-aware about the state of art techniques to analyze data, which has resulted in the dramatic improvement in data gathering. The study concludes that awareness of social responsibility and ethical dimensions will also place a positive impact on the performance improvement. The study recommended that there is need to develop effective programs for reducing medium and administrative corruption that outrageous the motivation of employees related to work ethics.

Michael and Okolie-Osemene (2017) conducted a study on workforce diversity and performance of Nigerian breweries plc, Enugu, Nigeria. The objective of the study was to examine workforce diversity and performance of Nigerian Breweries Plc, Enugu, while the study specifically ascertained the relationship existing between ethnic diversity and service delivery of Nigerian Breweries Plc, Enugu. The study adopted descriptive survey design. The study found out that there was a strong, positive relationship between ethnic diversity and the service delivery of Nigerian Breweries Plc, Enugu. The study recommended that the Nigerian Breweries Plc, Enugu should integrate diversity management into its management structure to ensure that organisational service delivery is enhanced through ethnic diversity.

Yang and Wei (2017) conducted a study on ethical leadership and employee task performance: Examining moderated mediation process. The purpose of this paper is to examine the impact of ethical leadership on employee task performance. the study adopted Multiple regression analysis. The findings indicate that ethical leadership positively influences employee task performance. The study concludes that employee task performance is critical for a firm's competitive advantage. The study recommended that knowledge about the relationship between ethical leadership and employee task performance and contributes to effective management.

Tamunomiebi and Iyioriobhe (2016) conducted a study on the diversity and ethical issues in the organizations in Port Harcourt, Nigeria. The study shows that organizations developed from the society which is made up of people with different diversity and ethics. The objective 
of the study was to examine the impact of ethical diversity on organizational development. The study concludes that diversity management is a strategy to promote the perception, acknowledgement and implementation of diversity in organizations and institutions. The study was a descriptive study in nature. The study recommended that management should adopt a high diversity culture for continuous change and improvement in the organization.

Amalina, Zunaidah and Ridzwana (2014) investigated on an analysis on ethical climate and ethical judgment among public sector employees in Malaysia. The study aims to analyse the influence of ethical judgments on the intention towards unethical behavioural practices among employees in selected Malaysian public sectors. The study adopted questionnaire survey method. The finding of this study has shown a positive significant relationship between ethical climate and ethical judgment of employees' behaviour on selected financial decisions in Malaysian public sectors. The study concludes that the first task of a government is to ensure the security of the country, both internal as well as external peace. White collar crime such as bribery should be controlled and the rule of law enforced. The study recommended that government needs to improve existing ethical climate by implementing the control and monitoring procedure of the employees at various departments of public sectors in order to enhance the ethical behavioural practices.

Tiemo and Arubayi (2012) examined the context of recruitment practices among Nigerian public and private firms. A comparative analysis of their recruitment practices were examined to determine if they adhered to the Nigerian Federal Character Principle (NFCP). Four pertinent research questions were raised and addressed and descriptive statistics was used to analyze the data collected from 42 human resource practitioners from both the public and private sectors. The public organizations include both federal and state ministries in Nigeria, while the private firms include both servicing and manufacturing companies. The results showed that there are unique similarities and differences in the recruitment practices of public and private firms. But with regard to NFCP policy adoption, public firms complied more than the private firms because they are directly regulated and controlled by the government. Private firms' recruitment patterns are contingent upon the perceived needs of the organizations. The findings also revealed that the recruitment approaches and orientations of public firms in UK differed greatly from those that practised in Nigeria. The study is relevant to every employer of labour as it highlights key areas they can improve upon to be able to bridge the inequality gap between men and women employees in Nigeria.

\subsection{Methodology}

The study based on the Ethical development and the growth of public sector in Nigeria. The area of study focused on 25 ministries of the public sector from South East, Nigeria made up of Enugu State: Ministry of Justice, Ministry of Information, Ministry Human Development and Poverty Reduction, Ministry of Agriculture and Natural Resources, Ministry of Finance and Economic Development, Anambra State: Ministry of Commerce and Industry, Ministry of Labour and Productivity, Ministry of Intergovernmental, Ministry of Rural Development, Ministry of Lands and Urban Development, Ebonyi State: Ministry of Capital Territory, Ministry of Youths and Sports, Ministry of Gender affairs and Social Development, Ministry of Education, Ministry of Health Imo State: Ministry of Environment and Mineral Resources, Ministry of Local Government, Ministry of Chieftaincy Matters, Ministry of Science and Technology, Ministry of Transport, Abia State: Ministry of Culture and Tourism, Ministry of Water resources, Ministry of Works and Infrastructures, Ministry of Housing, and Ministry of Budget and Planning. They also have high strength and operate on high ethical standards. They study covered period of (2010-2020). The study used the survey approach. The primary sources were personal interview and the administration of questionnaire to the management and staff of the manufacturing firms. The population for the study was Six thousand, seven 
hundred and thirteen staff $(6,713)$ of the ministries. The study sample size, Nine hundred and seventeen (363) respondents was chosen after applying the Freund and William's formula for the determination of adequate sample size. A total of three hundred and sixty three (363) copies of the questionnaire were distributed to the respondents from which three hundred and forty three (343) copies were returned while twenty copies (20) were not returned. That gave 95 percent response rate. The validity of the instrument was tested using content analysis and the result was good. The reliability was tested using the Pearson correlation coefficient (r). It gave a reliability co-efficient of 0.84 which was also good. Data was presented and analyzed by mean score (3.0 and above agreed while below 3.0 disagreed) and standard deviation using Sprint Likert Scale. The hypotheses were analyzed using Z-statistic tool with the aid of Statistical Package for Social Science (SPSS) version 20.

\subsection{Data Presentation Analysis}

4.1 Likert Scale Analyses

Research question one. What is the relationship between equality and employment opportunities in public sector in Nigeria?

Table 4.1: Responses to Research Question One: What is the relationship between equality and employment opportunities in public sector in Nigeria?

\begin{tabular}{|c|c|c|c|c|c|c|c|c|c|c|}
\hline & & $\begin{array}{l}5 \\
\text { SA }\end{array}$ & $\begin{array}{l}4 \\
\mathbf{A}\end{array}$ & $\begin{array}{l}\mathbf{3} \\
\mathbf{N}\end{array}$ & $\begin{array}{l}2 \\
\text { DA }\end{array}$ & $\begin{array}{l}1 \\
\text { SD }\end{array}$ & $\sum \boldsymbol{f} \mathbf{X}$ & $\overline{\mathbf{X}}$ & Std.D & Decision \\
\hline 1. & $\begin{array}{l}\text { The job information is } \\
\text { giving to all no matter } \\
\text { year race }\end{array}$ & $\begin{array}{l}100 \\
20 \\
5.8\end{array}$ & $\begin{array}{l}672 \\
168 \\
49.0\end{array}$ & $\begin{array}{l}162 \\
54 \\
15.7\end{array}$ & $\begin{array}{l}130 \\
65 \\
19.0\end{array}$ & $\begin{array}{l}72 \\
36 \\
10.5\end{array}$ & $\begin{array}{l}1136 \\
343 \\
100 \%\end{array}$ & 3.21 & 1.137 & Agree \\
\hline 2. & $\begin{array}{l}\text { All the employers receive } \\
\text { the same compensation } \\
\text { both male and female }\end{array}$ & $\begin{array}{l}560 \\
112 \\
32.7\end{array}$ & $\begin{array}{l}440 \\
110 \\
32.1\end{array}$ & $\begin{array}{l}114 \\
38 \\
11.1\end{array}$ & $\begin{array}{l}114 \\
57 \\
16.6\end{array}$ & $\begin{array}{l}26 \\
26 \\
7.5\end{array}$ & $\begin{array}{l}1254 \\
343 \\
100 \%\end{array}$ & 3.66 & 1.293 & Agree \\
\hline 3. & $\begin{array}{l}\text { Vacation policy for staff } \\
\text { is for all region in the } \\
\text { public sector }\end{array}$ & $\begin{array}{l}515 \\
103 \\
30.0\end{array}$ & $\begin{array}{l}288 \\
72 \\
21.0\end{array}$ & $\begin{array}{l}201 \\
67 \\
19.5\end{array}$ & $\begin{array}{l}94 \\
47 \\
13.7\end{array}$ & $\begin{array}{l}54 \\
54 \\
15.7\end{array}$ & $\begin{array}{l}1152 \\
343 \\
100 \%\end{array}$ & 3.36 & 1.434 & Agree \\
\hline 4. & $\begin{array}{l}\text { Positioning in the public } \\
\text { sector is based purely on } \\
\text { the employee } \\
\text { classification or level }\end{array}$ & $\begin{array}{l}695 \\
139 \\
44\end{array}$ & $\begin{array}{l}184 \\
46 \\
10\end{array}$ & $\begin{array}{l}168 \\
56 \\
18\end{array}$ & $\begin{array}{l}140 \\
70 \\
20\end{array}$ & $\begin{array}{l}32 \\
32 \\
6\end{array}$ & $\begin{array}{l}1219 \\
343 \\
100 \%\end{array}$ & 3.55 & 1.425 & Agree \\
\hline 5. & $\begin{array}{l}\text { The disabled same } \\
\text { opportunities others }\end{array}$ & $\begin{array}{l}430 \\
86 \\
25.1\end{array}$ & $\begin{array}{l}404 \\
101 \\
29.4\end{array}$ & $\begin{array}{l}168 \\
56 \\
16.3\end{array}$ & $\begin{array}{l}90 \\
45 \\
13.1\end{array}$ & $\begin{array}{l}55 \\
55 \\
16.0\end{array}$ & $\begin{array}{l}1147 \\
343 \\
100 \%\end{array}$ & 3.34 & 1.399 & Agree \\
\hline & $\begin{array}{l}\text { Total grand mean and } \\
\text { standard deviation }\end{array}$ & & & & & & & 3.43 & 1.338 & \\
\hline
\end{tabular}

Source: Field Survey, 2020

Table 4.1, agreed thatthe job information is giving to all no matter year race with mean score of 3.21 and standard deviation of 1.137. All the employers receive the same compensation both male and female with mean score of 3.66 and standard deviation of 1.293, Vacation policy for staff is for all region in the publicsector with mean score of 3.36and standard deviation of 1.434 ,Positioning in the public sector is based purely on the employee classification or levelwith mean score of 3.55and standard deviation of 1.425and The disabled same opportunities others with mean score of 3.34 and standard deviation of 1.399. 
Finally, it was agreed thatthere is a relationship between equality and employment opportunities in public sector in Nigeria, with grand mean score of 3.43 and total standard deviation of 1.338 .

Research Question Two. What is the relationship between technoethic and creation of infrastructure in public sector in Nigeria?

Table 4.2: Responses to Research Question Two: What is the relationship between Technoethic and creation of infrastructure in public sector in Nigeria?

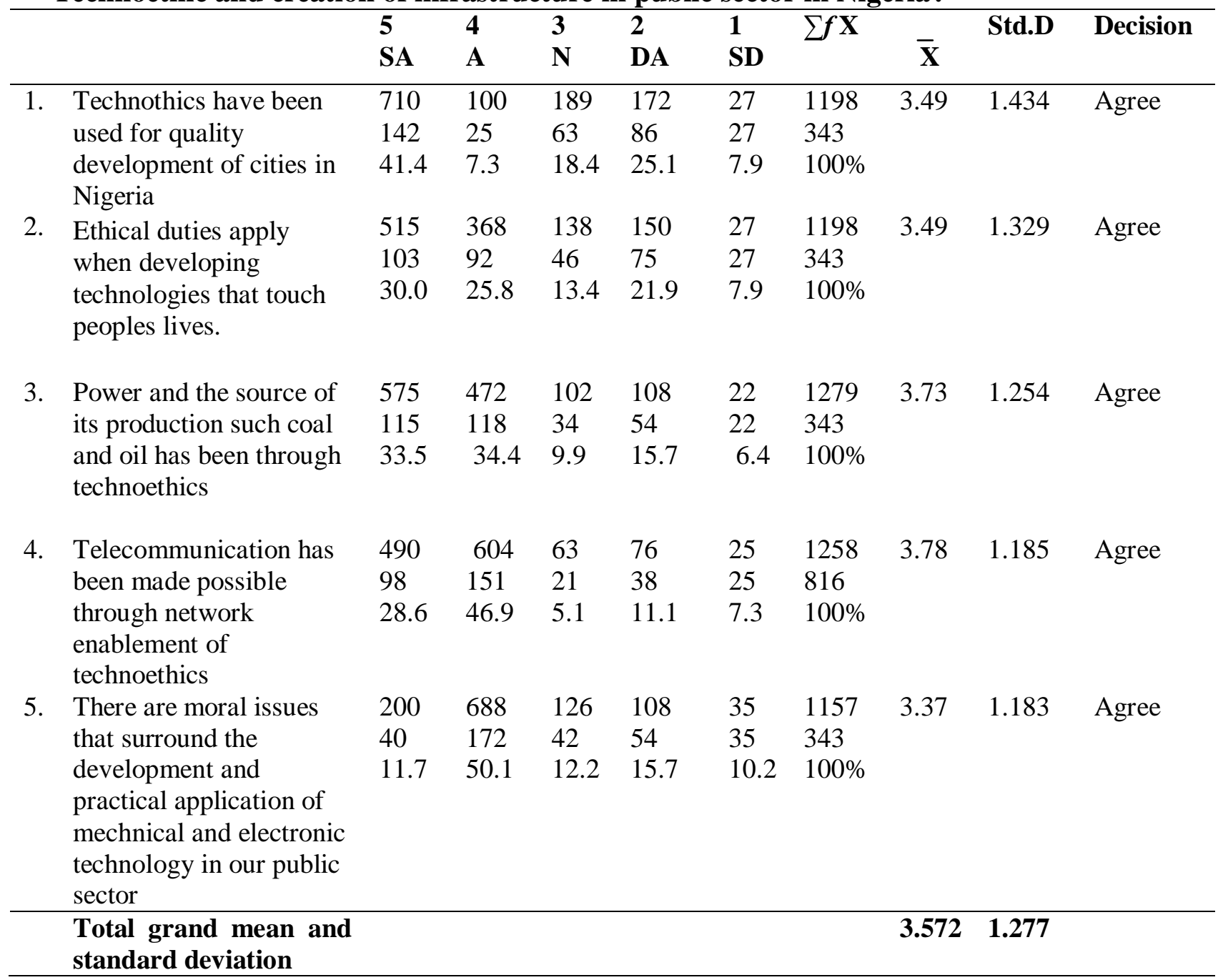

Source: Field Survey, 2020

Table 4.2, agreed thatTechnothics have been used for quality development of cities in Nigeria with mean score of 3.49 and standard deviation of 1.434. Ethical duties apply when developing technologies that touch peoples lives with mean score of 3.49 and standard deviation of 1.329, Power and the source of its production such coal and oil has been through technoethics with mean score of 3.73 and standard deviation of 1.254, Telecommunication has been made possible through network enablement of technoethics with mean score of 3.78 and standard deviation of 1.185 and There are moral issues that surround the development and practical application of mechnical and electronic technology in our public sector with mean score of 3.37and standard deviation of 1.183. Finally, it was agreed thatthere is 
arelationship between technoethic and creation of infrastructure in public sector in Nigeria with grand mean score of 3.572 and total standard deviation of 1.277.

Research Question Three: What is the relationship between diversity and generation of financial resources in public sector in Nigeria?

Table 4.3: $\quad$ Responses to Research Question Three: What is the relationship between diversity and generation of financial resources in public sector in Nigeria?

\begin{tabular}{|c|c|c|c|c|c|c|c|c|c|c|}
\hline & & $\begin{array}{l}5 \\
\text { SA }\end{array}$ & $\begin{array}{l}4 \\
\mathbf{A}\end{array}$ & $\begin{array}{l}\mathbf{3} \\
\mathbf{N}\end{array}$ & $\begin{array}{l}\text { DA } \\
\text { DA }\end{array}$ & $\begin{array}{l}1 \\
\text { SD }\end{array}$ & $\sum \boldsymbol{f} \mathbf{X}$ & $\overline{\mathbf{X}}$ & Std.D & Decision \\
\hline 1. & $\begin{array}{l}\text { Religion does not matter } \\
\text { in resource allocation in } \\
\text { the public sector in } \\
\text { Nigeria }\end{array}$ & $\begin{array}{l}605 \\
121 \\
35.3\end{array}$ & $\begin{array}{l}420 \\
105 \\
30.6\end{array}$ & $\begin{array}{l}123 \\
41 \\
12.0\end{array}$ & $\begin{array}{l}64 \\
32 \\
9.3\end{array}$ & $\begin{array}{l}44 \\
44 \\
12.8\end{array}$ & $\begin{array}{l}1256 \\
343 \\
100 \%\end{array}$ & 3.66 & 1.375 & Agree \\
\hline 2. & $\begin{array}{l}\text { Resource utilization } \\
\text { selects no gender }\end{array}$ & $\begin{array}{l}735 \\
147 \\
42.9\end{array}$ & $\begin{array}{l}320 \\
80 \\
23.3\end{array}$ & $\begin{array}{l}108 \\
36 \\
10.5\end{array}$ & $\begin{array}{l}108 \\
54 \\
15.7\end{array}$ & $\begin{array}{l}25 \\
25 \\
7.6\end{array}$ & $\begin{array}{l}1188 \\
343 \\
100 \%\end{array}$ & 3.78 & 1.343 & Agree \\
\hline 3. & $\begin{array}{l}\text { Ethnicity is not a barrier } \\
\text { to public revenue and } \\
\text { especially tax }\end{array}$ & $\begin{array}{l}360 \\
72 \\
21.0\end{array}$ & $\begin{array}{l}624 \\
156 \\
45.5\end{array}$ & $\begin{array}{l}90 \\
30 \\
8.7\end{array}$ & $\begin{array}{l}116 \\
58 \\
16.9\end{array}$ & $\begin{array}{l}27 \\
27 \\
7.9\end{array}$ & $\begin{array}{l}1217 \\
343 \\
100 \%\end{array}$ & 3.55 & 1.218 & Agree \\
\hline 4. & $\begin{array}{l}\text { The various cultural } \\
\text { background does not } \\
\text { influence the collectors } \\
\text { of public fund }\end{array}$ & $\begin{array}{l}200 \\
40 \\
11.7\end{array}$ & $\begin{array}{c}640 \\
160 \\
46.6\end{array}$ & $\begin{array}{l}117 \\
39 \\
11.4\end{array}$ & $\begin{array}{l}144 \\
72 \\
21.0\end{array}$ & $\begin{array}{c}32 \\
32 \\
9.3\end{array}$ & $\begin{array}{l}1133 \\
343 \\
100 \%\end{array}$ & 3.30 & 1.195 & Agree \\
\hline 5. & $\begin{array}{l}\text { There is common belief } \\
\text { in the issues tax } \\
\text { generations in the public } \\
\text { sector }\end{array}$ & $\begin{array}{l}485 \\
97 \\
28.3\end{array}$ & $\begin{array}{l}684 \\
171 \\
49.9\end{array}$ & $\begin{array}{l}66 \\
22 \\
6.4\end{array}$ & $\begin{array}{l}60 \\
30 \\
8.7\end{array}$ & $\begin{array}{l}23 \\
23 \\
6.7\end{array}$ & $\begin{array}{l}1318 \\
343 \\
100 \%\end{array}$ & 3.84 & 1.131 & Agree \\
\hline & $\begin{array}{l}\text { Total grand mean and } \\
\text { standard deviation }\end{array}$ & & & & & & & 3.626 & 1.252 & \\
\hline
\end{tabular}

\section{Source: Field Survey, 2020}

Table 4.3, agreed thatReligion does not matter in resource allocation in the public sector in Nigeria with mean score of 3.66and standard deviation of 1.375. Resource utilization selects no gender with mean score of 3.78and standard deviation of 1.343, Ethnicity is not a barrier to public revenue and especially tax with mean score of 3.55 and standard deviation of 1.218 , The various cultural background does not influence the collectors of public fund with mean score of 3.30and standard deviation of 1.195and There is common belief in the issues tax generations in the public sector with mean score of 3.84and standard deviation of 1.131. Finally, it was agreed thatthere is a relationship between diversity and generation of financial resources in public sector in Nigeria with grand mean score of 3.626 and total standard deviation of 1.252 . 


\subsection{Test of Hypotheses}

4.2.1 Hypothesis One:There is a significant relationship between equality and employment opportunities in public sector in Nigeria.

Table 4.2.1.1: Pearson Correlation onThere is a significant relationship between equality and employment opportunities in public sector in Nigeria.

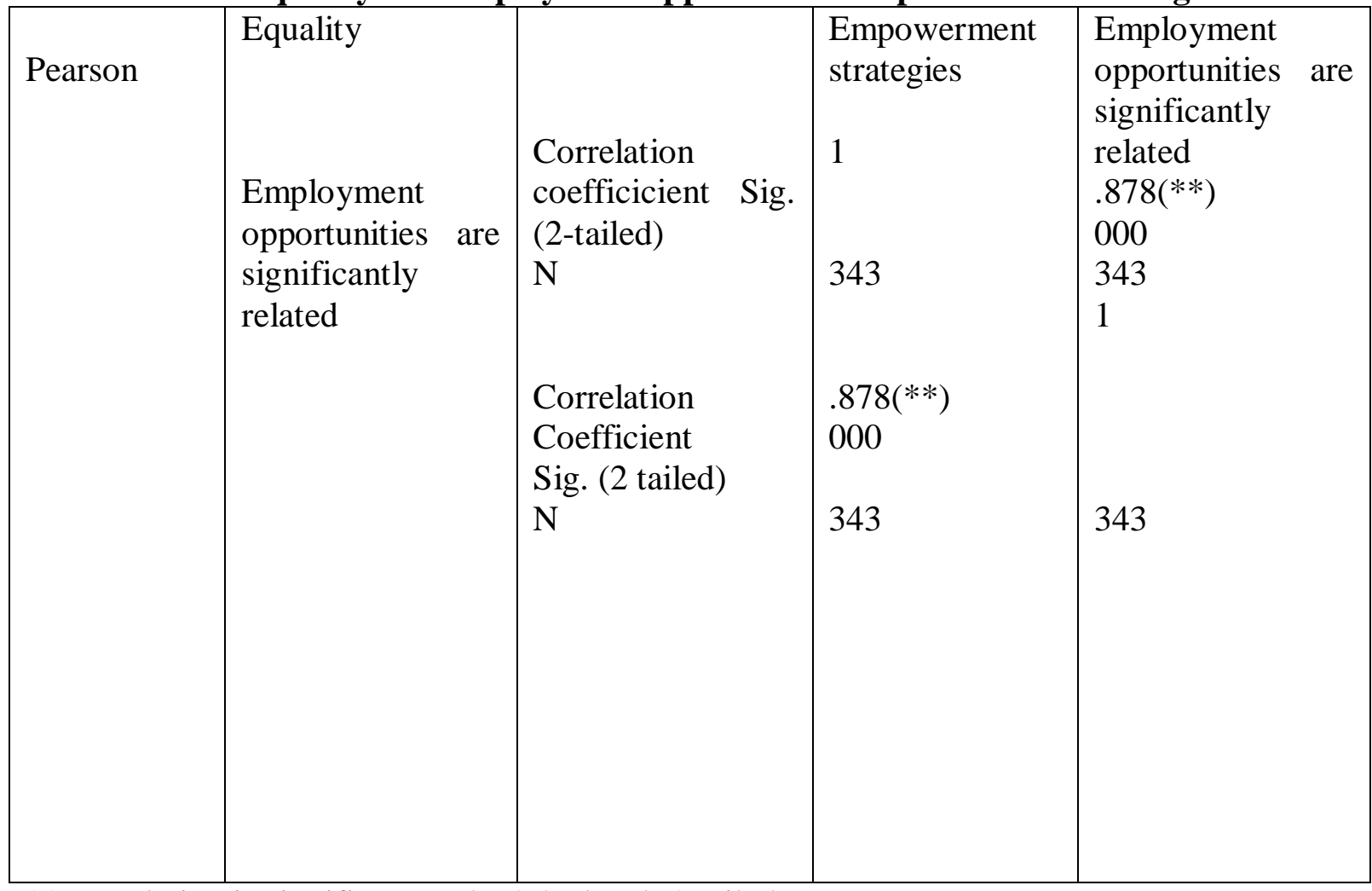

** correlation is significant at the 0.05 level ( 2 tailed)

Table 4.2.1.1 is the Pearson correlation matrix on the equality and employment opportunities in public sector in Nigeria showing the correlation coefficients, had significant values and the number of cases. The correlation coefficient shows 0.878 . This value indicates that correlation is significant at 0.05 level ( 2 tailed) and implies that There is a significant relationship between equality and employment opportunities in public sector in Nigeria( $(r=.878)$. The computed correlations coefficient is greater than the table value of $r=$ .195 with 879 degree of freedom $(\mathrm{df} .=\mathrm{n}-2)$ at alpha level for a two-tailed test $(\mathrm{r}=.88$, $\mathrm{p}<.05)$.

\section{Decision Rule}

The decision rule is to accept the null hypothesis if the computed $r$ is less than the tabulated $r$ otherwise reject the null hypothesis.

\section{Decision}

Since the computed $r=0.88$ is greater than the table value of .195 , we reject the null hypothesis. Therefore, we conclude thatthere is a significant relationship between equality and employment opportunities in public sector in Nigeria as reported in the probability value of $(\mathrm{r}=.88, \mathrm{p}<.05)$. 
4.2.2 Hypothesis Two: Technoethics and creation of infrastructure are significantly related

Table 4.2.2.1: Pearson Correlation on Technoethics and creation of infrastructure are significantly related

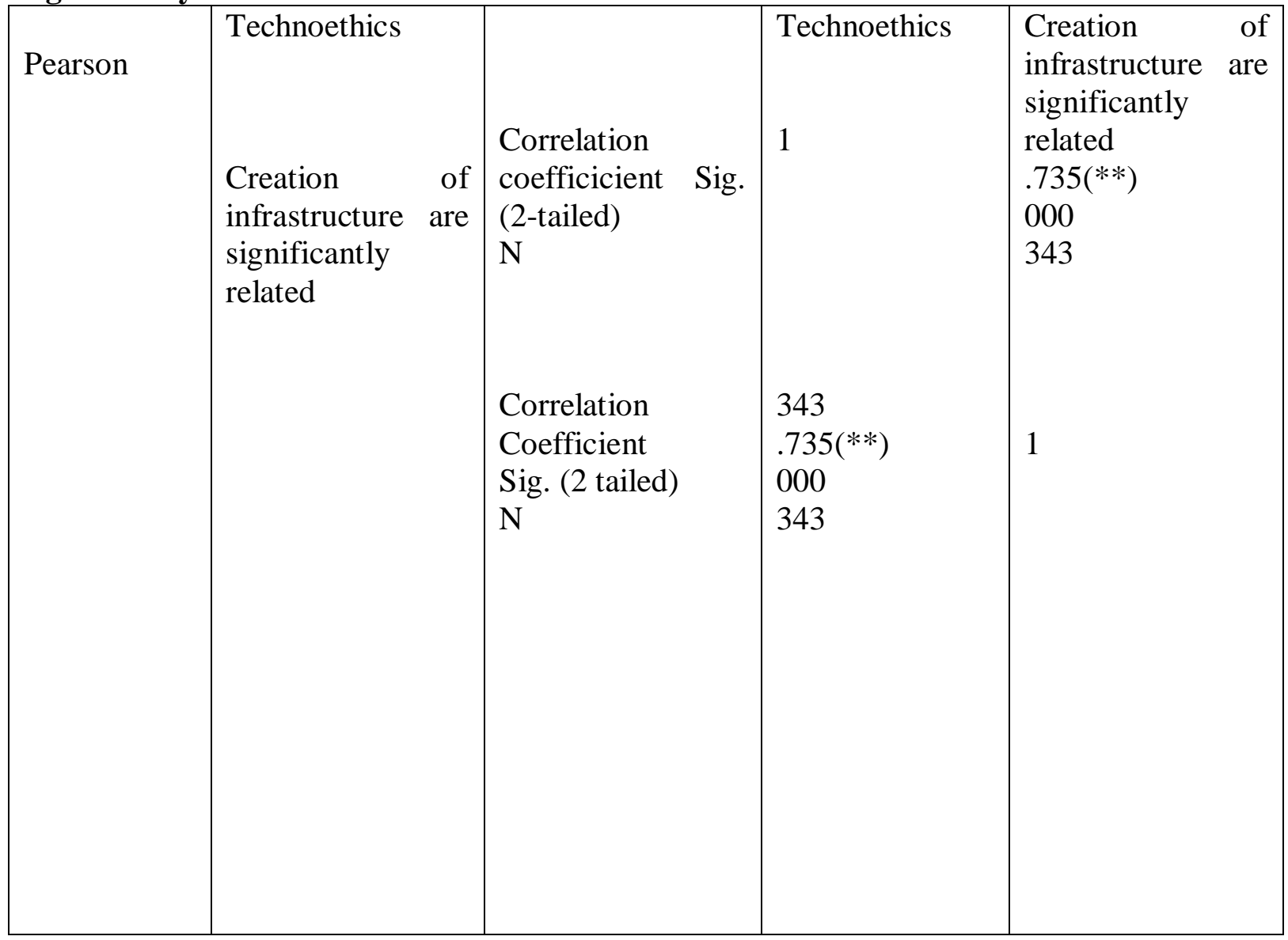

** correlation is significant at the 0.05 level ( 2 tailed)

Table 4.2.2.1 is the Pearson correlation matrix on the Technoethics and creation of infrastructure are significantly related showing the correlation coefficients, significant values and the number of cases. The correlation coefficient shows 0.735 . This value indicates that correlation is significant at 0.05 level ( 2 tailed) and implies that Technoethics and creation of infrastructure are significantly related $(\mathrm{r}=.735)$. The computed correlations coefficient is greater than the table value of $r=.195$ with 879 degree of freedom $(\mathrm{df} .=\mathrm{n}-2)$ at alpha level for a two-tailed test $(r=.74, \mathrm{p}<.05)$.

\section{Decision Rule}

The decision rule is to accept the null hypothesis if the computed $r$ is less than the tabulated $r$ otherwise reject the null hypothesis.

\section{Decision}

Since the computed $r=0.74$ is greater than the table value of .195 , we reject the null hypothesis. Therefore, we conclude that Technoethics and creation of infrastructure are significantly related as reported in the probability value of $(r=.74, p<.05)$. 
4.2.3 Hypothesis Three: Diversity and generation of financial resources in public sectors in Nigeria are significantly related.

Table 4.2.3.1: Pearson Correlation on Diversity and generation of financial resources in public sectors in Nigeria are significantly related.

\begin{tabular}{|c|c|c|c|c|}
\hline Pearson & $\begin{array}{l}\text { Diversity } \\
\\
\text { Generation of } \\
\text { financial } \\
\text { resource are } \\
\text { significantly } \\
\text { related }\end{array}$ & $\begin{array}{l}\text { Correlation } \\
\text { coefficicient } \\
\text { Sig. (2-tailed) } \\
\text { N } \\
\\
\text { Correlation } \\
\text { Coefficient } \\
\text { Sig. (2 tailed) } \\
\text { N }\end{array}$ & $\begin{array}{l}\text { Diversity } \\
1\end{array}$ & $\begin{array}{l}\text { Generation of } \\
\text { financial } \\
\text { resource are } \\
\text { significantly } \\
\text { related } \\
.679(* *) \\
000 \\
343 \\
1\end{array}$ \\
\hline
\end{tabular}

** correlation is significant at the 0.05 level ( 2 tailed)

Table 4.2.3.1 is the Pearson correlation matrix on the Diversity and generation of financial resources in public sectors in Nigeria are significantly related showing the correlation coefficients, significant values and the number of cases. The correlation coefficient shows 0.679 . This value indicates that correlation is significant at 0.05 level ( 2 tailed) and implies that Diversity and generation of financial resources in public sectors in Nigeria are significantly related $(\mathrm{r}=.679)$. The computed correlations coefficient is greater than the table value of $\mathrm{r}=.195$ with 879 degree of freedom $(\mathrm{df} .=\mathrm{n}-2)$ at alpha level for a two-tailed test $(\mathrm{r}=.68, \mathrm{p}<.05)$.

\section{Decision Rule}

The decision rule is to accept the null hypothesis if the computed $r$ is less than the tabulated $r$ otherwise reject the null hypothesis.

\section{Decision}

Since the computed $r=0.68$ is greater than the table value of .195 , we reject the null hypothesis. Therefore, we conclude that Diversity and generation of financial resources in public sectors in Nigeria are significantly related as reported in the probability value of $(\mathrm{r}=.68, \mathrm{p}<.05)$

\subsection{Discussion of Findings}

From the result hypothesis one, the computed $r=0.878$ is greater than the table value of .195 , we reject the null hypothesis. Therefore, we conclude thatthere is a significant relationship between equality and employment opportunities in public sector in Nigeria as reported in the probability value of ( $\mathrm{r}=.88, \mathrm{p}<.05)$. In support of the result, William, (2011) states that Equality before law means that the law applies to all peoples without exceptions, therefore the law must be designed beforehand in a way that discrimination by the state becomes unthinkable. Fairness and justice concept should be followed and enforced by the state and employment opportunities given to all. From the result hypothesis two, the computed $\mathrm{r}=$ 0.735 is greater than the table value of .195 , we reject the null hypothesis. Therefore, we 
conclude thatTechnoethics and creation of infrastructure are significantly related as reported in the probability value of $(\mathrm{r}=.74, \mathrm{p}<.05)$.In support of the above result, Mike, (2017) opines that Technoethics views technology and ethics as socially embedded enterprises and focuses on discovering the ethical use of technology, protecting against the misuse of technology, and devising common principles to guide new advances in technological development and application to benefit society. From the result hypothesis three, the computed $r=0.679$ is greater than the table value of .195, we reject the null hypothesis. Therefore, we conclude that Diversity and generation of financial resources in public sectors in Nigeria are significantly related as reported in the probability value of $(\mathrm{r}=.68, \mathrm{p}<.05)$.In support of the above result, Vaux and Michelle (2019) assert that the modern companies often strive for greater diversity among their employees, hiring workers of different races, creeds, genders and ages to bring a more varied experience to their ranks.

\section{Conclusion.}

The study concluded that there is a relationship between equality, technoethics, diversity and employment opportunities, creation of infrastructure, and generation of financial resources in the public sector in Nigeria. An ethical development is essential for a society to function properly. Individuals that behave unethically will normally loss other people's confidence and their unethical behaviour should be also punished by the law. The performance of an organization is sometimes based on the ethical work environment. The public sector might provide services that non-payer cannot be excluded from (such as street lighting), services which benefit all of society rather than just the individual who uses the service (such as public education), and services that encourage equal opportunity. In Performing the role of technoethicists HR can at least make sure that the proper consideration is given to the people versus technology decisions that management teams will make. A company that can successfully manage a diverse workplace has a solid advantage over companies that do not embrace diversity so readily. A diverse workplace may facilitate employment in far-flung parts of the world.

\section{Recommendation}

Based on the findings of the study, the following recommendations were made:

i. Ethical use of technology should be encouraged by devising thoughtful principles that could help to guide new technological advances in public sector in Nigeria.

ii. There should be a standardized moral principles guiding the recruitment and selection process of employment in public sector in Nigeria

iii. Diversity in public sector workplace should be encouraged in order to survive competitive environment.

\section{References}

1. Amalina, A., Zunaidah, S. and Ridzwana, M.S. (2014).An analysis on ethical climate and ethical judgment among public sector employees in Malaysia.Journal of Applied Business and Economics, 16(2); 1- 10.

2. Bivins, D. (2010). Development ethics: An emergent field? in R. Prendergast and F. Stewart (eds.) Market Forces and World Development, London: Macmillan; New York: St. Martin's Press.

3. Crocker, D. A. (2013).Toward development ethics. World Development.19 (5): 457-483.

4. Dube, S. and Danescu, D. (2011) Supplementary Guidance: Public sector definition.Institute of Internal Affairs Publication. Florida, USA. 
5. Equality and Human Rights Commission (2018) Understanding equality. Retrieved from https://www.equalityhumanrights.com/en/secondary-education-resources/usefulinformation/understanding-equality

6. Fulmer, Jeffrey (2009). "What in the world is infrastructure?". PEI Infrastructure Investor (July/August): 30-32.

7. International Labour Organization (2018) GUide on measuring decent jobs for youth. Retrieved from https://www.ilo.org/wcmsp5/groups/public/---ed_emp/documents/

8. Jochimsen, R., Ed. (1966). Theorie der Infrastruktur: Grundlagen der marktwirtschaftlichenEntwicklung. Tübingen, J.C.B. Mohr

9. Kehinde, O.J. (2017). Effects of ethical behaviour on organizational performance: Evidence from three service organizations in Lagos, Nigeria. Journal of Research in National Development, 8(1);1-17

10. Lucy, William (2011)."Equality under and before the law". The University of Toronto Law Journal. 61 (3): 411-465. doi:10.3138/utlj.61.3.41

11. Luppicini, R. (2010).Technoethics and the evolving knowledge society. Hershey: Idea Group Publishing.

12. Mahjob, J. A.A. (2018). The role of business ethics in improving the quality of job performance.Journal Entrepreneurship Organization Management, 7: 2-24.

13. Management Study Guide Content Team (2015).Organization ethics - meaning and its importance. Retrieved from https://www.managementstudyguide.com/organizationethics.htm.

14. Michael, A. I. and Okolie-Osemene, M. (2017).Workforce diversity and performance of Nigerian breweries plc, Enugu, Nigeria.Global Journal of Human Resource Management,5(7);62-78

15. Mike, H. (2017). Is the future of HR technoethics? Retrieved from https://workology.com/ is-the-tuture-of-hr-technoethics/.

16. Montana, P. J and Charnov, B. H. (2008).Management - 4th edition; (2008) - Barron's Educational Series, Inc.

17. Moor, J. H. (2005). Why we need better ethics for emerging technologies. Ethics and Information Technology.Pp.111-119.

18. Natter, E. 2019). Define diversity in the workplace. Retrieved from https://smallbusiness.c hron.com/define-diversity-workplace-4926.html.

19. O'Sullivan, Arthur; Sheffrin, Steven M. (2003). Economics: Principles in Action. Upper SaddleRiver, NJ: Pearson Prentice Hall. p. 474. ISBN 978-0-13-063085-8.

20. Rich, K. L. (2013) Introduction to Ethics.JOnes\& Bartlett Learning, LLC

21. Robert, P. (2003). Stakeholder Theory and Organizational Ethics. p. 42-66.

22. Robert, S.F. and Schlacter (1999).Motivating employees to act ethically: An expectancy theory approach.Journal of Business Ethics, 18(3);295-304

23. Sebag-Montefiore, L. (2015). What are the benefits of diversity in the workplace? https://theundercoverrecruiter.com/benefits-diversity-workplace/.

24. Stephen P. (2009). Technoethics (TE). Retrieved from https://blogs.ubc.ca/hwlmt/2009/08 /15/technoethics-te/

25. Sternberg, R. J. (2012). A model for ethical reasoning.Review of General Psychology, 16, 319-326.

26. Tamunomiebi, M. D., and Ehior, I. E. (2019).Diversity and ethical issues in the organizations.International Journal of Academic Research in Business and Social Sciences, 9(2), 839-864.

27. Tiemo, J. A. and Arubayi, D. O. (2012) Recruitment practices in Nigeria: Issues of Equality and Diversity. Journal of Emerging Trends in Economics and Managment Sciences, Vol. 3,m No.3, pp. 210-213 
28. Torrisi, G. (2009) Public Infrastructure; definition, classification and measurements. University of Catania, DEMQ

29. Vaux, R. and Michelle, S. (2019). How does diversity affect the workplace. https://smallbusiness.chron.com/diversity-affect-workplace-10510.html.

30. Yang, Q. and Wei, H. (2017). Ethical leadership and employee task performance: examining moderated mediation process. Management Decision, 55(7); 1506-1520. 